\title{
Increased sulfiredoxin-1 levels as compensatory mechanism against reactive oxygen species in women with gestational diabetes mellitus
}

\section{Gestasyonel diabetes mellituslu kadınlarda reaktif oksijen türlerine karşı telafi edici bir mekanizma olarak sülfiredoksin-1 düzeyleri artmaktadır}

\author{
(1) Burak Tatar, (1) Uğur Turhan \\ University of Health Sciences Turkey, Samsun Training and Research Hospital, Clinic of Obstetrics and Gynecology, Samsun, Turkey
}

\begin{abstract}
Objective: This study aimed to investigate the correlation between serum Sulfiredoxin-1 (Srx-1) levels and gestational diabetes mellitus (GDM). Materials and Methods: A total of 40 patients diagnosed with GDM according to the American Diabetes Association Criteria and 40 age matched and gestational age-matched healthy pregnant women as a control group were included in this cross-sectional study. Serum Srx-1 levels and other demographic and laboratory variables were analyzed.

Results: Fasting plasma glucose, first and second-hour plasma glucose levels, fasting insulin levels, homeostasis model assessment of insulin resistance (HOMA-IR), and Srx-1 levels were significantly different in patients with GDM than control ( $<<0.05$ ). Plasma Srx-1 levels significantly correlated with fasting plasma glucose, first and second-hour plasma glucose levels, fasting insulin levels, and HOMA-IR of patients with GDM (p<0.05), whereas no correlation in the control group.

Conclusion: This is the first study demonstrating an association between serum Srx-1 levels and GDM. Our results suggest increased serum Srx-1 levels may be a novel predictive marker for GDM. More randomized-controlled trials are needed to evaluate Srx-1 as a marker for adverse fetal results; closer monitoring is warranted with high Srx-1 levels.
\end{abstract}

Keywords: Sulfiredoxin-1, gestational diabetes mellitus, pregnancy, peroxiredoxin, reactive oxygen species

Öz

Amaç: Bu çalışma serum Sülfiredoksin-1 (Srx-1) düzeyleri ile gestasyonel diabetes mellitus (GDM) arasında bir korelasyon olup olmadığını araştırmayı amaçlamaktadır.

Gereç ve Yöntemler: Amerikan Diyabet Derneği Kriterleri'ne göre GDM tanısı alan toplam 40 hasta ve kontrol grubu olarak yaş ve gebelik haftası eşleşen 40 sağlıklı gebe bu kesitsel çalışmaya dahil edildi. Serum Srx-1 düzeyleri ile diğer demografik ve laboratuvar değişkenleri analiz edildi.

Bulgular: Açlık plazma glukoz, birinci ve ikinci saat plazma glikoz düzeyleri, açlık insülin düzeyleri, insülin direncinin homeostaz modeli değerlendirmesi (HOMA-IR) ve Srx-1 düzeyleri GDM hastalarında kontrol grubundan anlamlı olarak farklıydı (p<0,05). Plazma Srx-1 düzeyleri açlık plazma glikoz, birinci ve ikinci saat plazma glikoz düzeyleri, açlık insülin düzeyleri ve GDM hastalarının HOMA-IR $(\mathrm{p}<0,05)$ ile anlamlı olarak ilişkiliyken, kontrol grubu için bir korelasyon yoktu.

Sonuç: Bu çalışma, serum Srx-1 düzeyleri ile GDM arasındaki ilişkiyi gösteren ilk çalışmadır. Sonuçlarımız, serum Srx-1 seviyelerinin artmasının GDM için yeni bir belirteç olarak kullanılabileceğini göstermektedir. Srx-l'in advers fetal sonuçların bir göstergesi olup olmadığını değerlendirmek için daha fazla randomize kontrollü çalışmaya ihtiyaç vardır; böylece yüksek Srx-1 seviyeleri olan hastalara daha yakın izleme gereksinimi belirlenebilir. Anahtar Kelimeler: Sülfiredoksin-1, gestasyonel diabetes mellitus, gebelik, peroksiredoksin, reaktif oksijen türleri

PRECIS: This is the first study to demonstrate an association between serum Srx-1 levels and gestational diabetes mellitus.

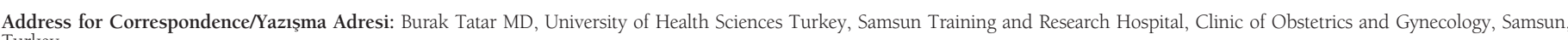
Turkey

Phone: +90 5333479571 E-mail: buraktatar@yahoo.com ORCID ID: orcid.org/0000-0002-6495-0174

Received/Geliș Tarihi: 01.09.2021 Accepted/Kabul Tarihi: 27.09.2021

${ }^{\circledR}$ Copyright 2021 by Turkish Society of Obstetrics and Gynecology

Turkish Journal of Obstetrics and Gynecology published by Galenos Publishing House. 


\section{Introduction}

Gestational diabetes mellitus (GDM) is defined as carbohydrate intolerance with an onset during pregnancy ${ }^{(1)}$. GDM is associated with a higher risk of complications, such as preeclampsia, increased cesarean delivery, macrosomia, birth trauma, and neonatal hypoglycemia ${ }^{(2,3)}$. The risk of type $2 \mathrm{DM}$ increases and offspring of these women also have an increased risk of developing DM later in life ${ }^{(4)}$.

Peroxiredoxins (Prxs) are a family of bifunctional proteins that are involved in chaperone and antioxidant activities controlling cytokine-induced peroxide levels, which are also involved in signal transduction ${ }^{(5,6)}$. Reduced Peroxiredoxin reduces hydrogen peroxide and alkyl hydroxiperoxides therefore becomes oxidized and reduced back by thioredoxin ${ }^{(7)}$. Murine knock-out models revealed that Prxl inactivation reduces the lifespan by 15\% and Prx 6 and Prx 3 knock-out models display no obvious pathology but a more sensitive phenotype to oxidative stress ${ }^{(8-10)}$. Prxs are also involved in the circadian rhythm of many species ${ }^{(11,12)}$.

Sulfiredoxin (Srx) is a redox protein discovered in $1994^{(13)}$. The cysteine-sulfinic acid residues of certain Prxs are selectively reduced by Srx and play an important role in oxidative stress resistance, thereby affecting Prx in regulating downstream transcription factors and kinase pathways ${ }^{(14)}$. Glutathionylation is an important post-translational modification of proteins. Many diseases, such as Parkinson's disease and DM, correlated with increased glutathionylation of specific proteins ${ }^{(15,16)}$. Srx is also involved in the deglutathionylation of proteins and is a potential target of treatment ${ }^{(16)}$.

Hyperglycemia induces reactive oxygen species (ROS) and is responsible for many DM complications ${ }^{(17)}$. Consequently, the organism produces antioxidants to compensate ROS, in the form of Prx and its function, are restored via Srx. Srx expression is significantly increased to protect Prxs in diabetic rats ${ }^{(18)}$. In addition, Srx-1 protects podocytes from high glucose-induced injury by activating Nrf2/ARE signaling ${ }^{(19)}$. As GDM similarly affects the fetus to type $2 \mathrm{DM}$, our hypothesis was that serum Srx-1 levels increased in hyperglycemic conditions such as GDM, which leads to ROS generation.

The literature revealed no previous report of human Srx-1 levels in women with GDM. This study aimed to investigate the correlation between SRx-1 levels and GDM.

\section{Materials and Methods}

A cross-sectional analysis of maternal plasma levels of Srx-1 between January 2019 and February 2020 was performed in 40 patients diagnosed with GDM according to the American Diabetes Association Criteria in their routine screening of $75 \mathrm{~g}$ oral glucose tolerance test (OGTT) between 24 and 28 gestational weeks. The control group was 40 gestational-age and age-matched healthy pregnant women with normal $75 \mathrm{~g}$ OGTT screening results. The inclusion criteria were singleton pregnancy and gestational age between 24 and 28 weeks.
The exclusion criteria were patients with chronic diseases, DM history, hypertension history, multiple pregnancies, and maternal or fetal conditions that require preterm delivery, such as pre-eclampsia, preterm labor, or intrauterine growth retardation, and any fetal anomaly.

All patients were followed from the first trimester of pregnancy, and the crown-rump length at the first visit was the reference for the last menstrual period day. The study was approved by the local ethics committee in Health Sciences University Samsun Research and Training Hospital, the approval number SBUSEAH/KAEK 2019/2/12.

Serum Srx-1 concentration was measured using an enzyme immunoassay (catalog no: EH15392, Wuhan Fine Biological Technology Co., LTD., China) with a minimum detectable concentration of $0.313 \mathrm{ng} / \mathrm{mL}$ and intra- and inter-assay variation coefficients of $<8 \%$ and $10 \%$, respectively. Absorbance at $450 \mathrm{~nm}$ was measured using a Smart Microplate Reader 16.1 (USCN KIT INC.). The optical density was read on a standard automated plate at $450 \mathrm{~nm}$ (1420 Victor 3; Perkin Elmer, Waltham, MA). Insulin resistance is calculated using the homeostasis model assessment of insulin resistance (HOMAIR). The HOMA-IR is calculated as follows: fasting glucose $\times$ (mmol) fasting insulin $(\mathrm{lU} / \mathrm{mL}) / 22.5$.

Written informed consent for study participation and blood sample collection was obtained from all participants, according to the principles outlined by the Declaration of Helsinki (2013).

\section{Statistical Analysis}

The Statistical Package for the Social Sciences version 20 (SPSS Inc., Chicago, IL) was used for the statistical analyses. Data are presented as mean \pm standard deviation. The categorical variables were expressed as percentages and the continuous variables were expressed as median (minimum and maximum). Correlations were assessed using Pearson and Spearman's correlation coefficient and a p-value $<0.05$ is considered statistically significant.

\section{Results}

The demographic, clinical, and laboratory characteristics of patients in GDM and control groups are demonstrated in Table 1. Fasting plasma glucose, first and second-hour plasma glucose levels, fasting insulin levels, HOMA-IR, and Srx-1 levels were significantly different in patients with GDM than that of the control group $(\mathrm{p}<0.05)$.

Plasma Srx-1 levels significantly correlated with fasting plasma glucose, first and second-hour plasma glucose levels, fasting insulin levels, and HOMA-IR in patients with GDM, whereas no correlation in the control group was observed (Table 2).

The median Srx-1 level in GDM group was higher than in the control group $(474.6 \pm 109 \mathrm{pg} / \mathrm{mL}$ vs. $316.7 \pm 48 \mathrm{pg} /$ $\mathrm{mL}$, respectively, $\mathrm{p}<0.01$ ) (Figure 1 ). The receiver operating characteristic curve for blood Srx-1 concentrations in the GDM group is demonstrated in Figure 2. The area under the curve 
Table 1. Clinical characteristics of GDM and control groups

\begin{tabular}{|c|c|c|c|}
\hline & GDM $(n=40)$ & $\begin{array}{l}\text { Control } \\
(n=40)\end{array}$ & $\mathrm{p}$ \\
\hline \multicolumn{4}{|l|}{ Value } \\
\hline Age (years) & $29.9 \pm 2.8$ & $29.2 \pm 4.6$ & 0.438 \\
\hline BMI $\left(\mathrm{kg} / \mathrm{m}^{2}\right)$ & $25.1 \pm 2.1$ & $24.8 \pm 2.6$ & 0.494 \\
\hline FPG (mg/dL) & $87.3 \pm 12.4$ & $72.7 \pm 4.8$ & $0.001 *$ \\
\hline GlH (mg/dL) & $164.4 \pm 14.5$ & $125 \pm 13.2$ & $0.001 *$ \\
\hline G2H (mg/dL) & $133 \pm 12$ & $107 \pm 10$ & $0.001 *$ \\
\hline FI (lU/mL) & $14.5 \pm 4.1$ & $8.9 \pm 2.2$ & $0.001 *$ \\
\hline HOMA-IR & $2.3 \pm 0.7$ & $0.8 \pm 0.7$ & $0.001 *$ \\
\hline HbAlc & $4.94 \pm 0.3$ & $4.86 \pm 0.2$ & 0.074 \\
\hline GA at drawing & $25.8 \pm 1.4$ & $25.5 \pm 1.3$ & 0.310 \\
\hline GA at birth & $38.4 \pm 0.9$ & $39.4 \pm 1.0$ & $0.001^{*}$ \\
\hline Birth weight (g) & $3705 \pm 300$ & $3265 \pm 174$ & $0.001^{*}$ \\
\hline SRX-1 (pg/mL) & $474.6 \pm 109$ & $316.7 \pm 48$ & $0.001 *$ \\
\hline
\end{tabular}

Data are expressed as mean $( \pm$ SD), GDM: Gestational diabetes mellitus, BMI: Body mass index, FPG: Fasting plasma glucose level, GlH: First-hour plasma glucose level, G2H: Second-hour plasma glucose level, FI: Fasting insulin level, HOMA-IR: Homeostasis model assessment of insulin resistance

was 0.938 (95\% confidence interval: 0.89-0.986). The optimal cut-off value was $362 \mathrm{pg} / \mathrm{mL}$ and ratios above this value were $80.5 \%$ sensitivity, $82.5 \%$ specificity, $77.5 \%$ positive predictive value, and $82.5 \%$ negative predictive value $(\mathrm{p}=0.0001)$.

\section{Discussion}

The present study showed that serum Srx levels were significantly higher in patients with GDM than in healthy pregnant women. In addition, fasting plasma glucose, first and second-hour blood glucose levels, and HOMA-IR results correlated with Srx-1 levels.

ROS formation in diabetes by glucose oxidation, nonenzymatic glycation of proteins, and lipid peroxidation lead to cellular protein damage and higher insulin resistance due to oxidative stress $^{(20)}$. Contrarily, ROS are produced, with a negative effect on insulin signaling, leading to insulin resistance, which is the pathophysiology for type $2 \mathrm{DM}$ in response to insulin ${ }^{(21)}$. Antioxidant administrations improved insulin resistance, which also suggests the involvement of ROS in insulin resistance progression ${ }^{(22)}$. Increased glucocorticoids and insulin-like growth factor in the placenta in GDM increases ROS due to increased glucose utilization and mitochondrial activity, similar to $\mathrm{DM}^{(23)}$.

Insulin resistance in pregnancy is a natural process that aims increased glucose transportation to the fetus. This natural process exaggerates if insulin secretion is not increased to compensate for insulin resistance, leading to GDM development, particularly with pancreatic beta-cell dysfunction ${ }^{(24,25)}$.
Table 2. Correlation analyses between serum SRX-1 and clinical parameters

\begin{tabular}{|c|c|c|}
\hline \multicolumn{3}{|l|}{ SRX-1 n (40) } \\
\hline GDM & r & $\mathrm{p}$-value \\
\hline Age & -0.215 & 0.182 \\
\hline BMI & -0.164 & 0.313 \\
\hline FPG & 0.503 & 0.001 \\
\hline GL1H & 0.365 & 0.001 \\
\hline GL2H & 0.483 & 0.02 \\
\hline FI & 0.339 & 0.032 \\
\hline Hbalc & 0.197 & 0.224 \\
\hline HOMA-IR & 0.32 & 0.044 \\
\hline GA at sampling & -0.083 & 0.097 \\
\hline GA at birth & -0.256 & 0.111 \\
\hline Birth weight & 0.1 & 0.54 \\
\hline \multicolumn{3}{|l|}{ SRX-1 n (40) } \\
\hline (b) Control Group & r & $\mathrm{p}$-value \\
\hline Age & 0.061 & 0.7 \\
\hline BMI & 0.216 & 0.18 \\
\hline FPG & 0.187 & 0.247 \\
\hline GLlH & 0.3 & 0.06 \\
\hline GL2H & 0.038 & 0.818 \\
\hline FI & 0.123 & 0.448 \\
\hline Hbalc & -0.175 & 0.281 \\
\hline HOMA-IR & 0.215 & 0.183 \\
\hline GA at sampling & 0.009 & 0.957 \\
\hline GA at birth & -0.204 & 0.207 \\
\hline Birth weight & -0.019 & 0.908 \\
\hline
\end{tabular}

p-values for Pearson's correlation, GDM: Gestational diabetes mellitus, BMI: Body mass index, FPG: Fasting plasma glucose level, G1H: First-hour plasma glucose level, G2H: Second-hour plasma glucose level, FI: Fasting insulin level, HOMA-IR: Homeostasis model assessment of insulin resistance

According to considerable evidence, Prxs act as antioxidants in eukaryotic cells and silence Srx, leading to Prxs hyperoxidation ${ }^{(18,26)}$. Congenital deficiency leads to neurodegenerative diseases and tumors, such as thyroid, breast, and lung cancer ${ }^{(15,16,27,28)}$.

Srx, as an antioxidant enzyme, was not extensively studied in-vivo. Thus, Srx was not previously studied in GDM either. In-vitro studies demonstrated that Srx-1 alleviates podocyte injury caused by ROS generated in diabetic nephropathy and cardiopathy ${ }^{(18,19)}$. Before the study, hyperglycemic GDM condition, which generates ROS, was hypothesized to increase serum Srx-1 levels. The 2-hour OGTT revealed blood glucose 


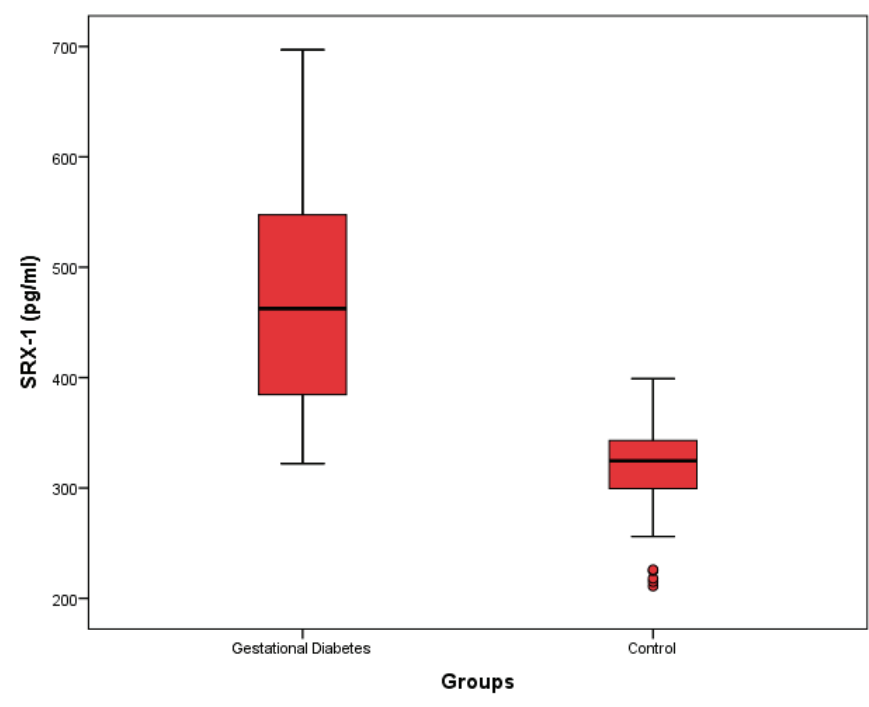

Figure 1. Srx-1 levels between GDM and control groups GDM: Gestational diabetes mellitus, Srx-1: Sulfiredoxin-1

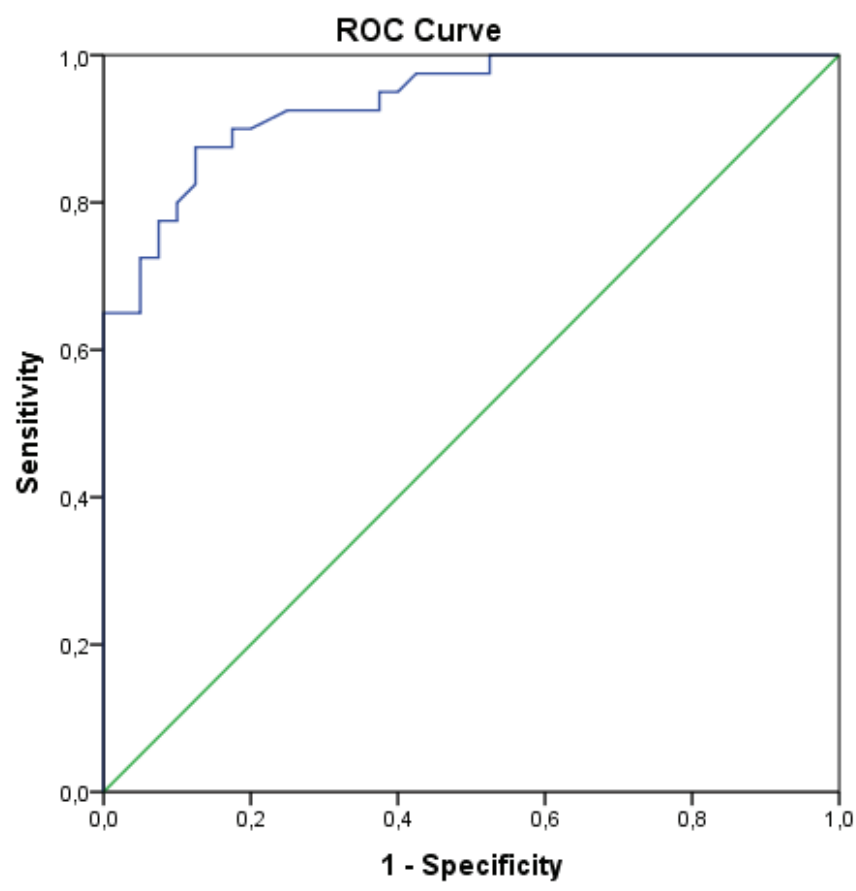

Diagonal segments are produced by ties.

Figure 2. ROC curve for Srx-1 levels in GDM

GDM: Gestational diabetes mellitus, ROC: Receiver operating characteristic, Srx-1: Sulfiredoxin-1

level fluctuation that is significantly associated with beta-cell dysfunction, oxidative stress, and inflammation ${ }^{(29)}$. Our study revealed that the first-hour blood glucose levels in patients with GDM $(164.4 \pm 14.5$ in GDM vs. $125 \pm 13.2$ in controls) significantly correlates with Srx-1 levels (474.6 in GDM \pm 109 vs. $316.7 \pm 48$ in controls). These results suggest that increased serum Srx-1 levels are used as a novel predictive marker for GDM.

\section{Study Limitations}

As the design of this study, obstetric outcomes were not evaluated between patients with high and low Srx levels, which is a limitation. In addition, the study had a small sample size and postpartum levels of Srx were not measured. Ergo, associations with obstetric outcomes and Srx-1 levels were not made. Nevertheless, elevated levels of Srx-1 are also associated with adverse gestational conditions, such as pre-eclampsia, intrauterine growth retardation, or placental implantation defects, with elevated ROS, which is beyond the scope of our preliminary study and requires further research ${ }^{(30)}$.

\section{Conclusion}

This is the first study to demonstrate an association between serum Srx-1 levels and GDM. More randomized-controlled trials are needed to evaluate Srx-1 as a marker of adverse fetal results; then, closer monitoring is warranted with high Srx-1 levels.

\section{Ethics}

Ethics Committee Approval: The study was approved by the local ethics committee in Health Sciences University Samsun Research and Training Hospital, with approval number SBUSEAH/KAEK 2019/2/12.

Informed Consent: Written informed consent for study participation and blood sample collection was obtained from all participants, according to the principles outlined by the Declaration of Helsinki (2013).

Peer-review: Externally and internally peer-reviewed.

\section{Authorship Contributions}

Concept: U.T., Design: B.T., Data Collection or Processing: B.T., Analysis or Interpretation: U.T., Literature Search: U.T., Writing: B.T.

Conflict of Interest: No conflict of interest was declared by the authors.

Financial Disclosure: The authors declared that this study received no financial support.

\section{References}

1. ACOG Practice Bulletin No. 190: gestational diabetes mellitus. Obstet Gynecol 2018;131:e49-64. doi: 10.1097/ AOG.0000000000002501.

2. Yogev Y, Xenakis EM, Langer $O$. The association between preeclampsia and the severity of gestational diabetes: the impact of glycemic control. Am J Obstet Gynecol 2004;191:1655-60.

3. Ehrenberg HM, Durnwald CP, Catalano P, Mercer BM. The influence of obesity and diabetes on the risk of cesarean delivery. Am J Obstet Gynecol 2004;191:969-74.

4. Kim C, Newton KM, Knopp RH. Gestational diabetes and the incidence of type 2 diabetes: a systematic review. Diabetes Care 2002;25:1862-8.

5. Rhee SG, Chae HZ, Kim K. Peroxiredoxins: a historical overview and speculative preview of novel mechanisms and emerging concepts in cell signaling. Free Radic Biol Med 2005;38:1543-52. 
6. Hofmann B, Hecht HJ, Flohe L. Peroxiredoxins. Biol Chem 2002;383:347-64.

7. Rhee SG, Kang SW, Chang TS, Jeong W, Kim K. Peroxiredoxin, a novel family of peroxidases. IUBMB Life 2001;52:35-41.

8. Neumann CA, Krause DS, Carman CV, Das S, Dubey DP, Abraham JL, et al. Essential role for the peroxiredoxin Prdxl in erythrocyte antioxidant defence and tumour suppression. Nature 2003;424:5615.

9. Muller FL, Lustgarten MS, Jang Y, Richardson A, Van Remmen H. Trends in oxidative aging theories. Free Radic Biol Med 2007;43:477-503.

10. Rhee SG, Kang SW, Jeong W, Chang TS, Yang KS, Woo HA. Intracellular messenger function of hydrogen peroxide and its regulation by peroxiredoxins. Curr Opin Cell Biol 2005;17:183-9.

11. O'Neill JS, van Ooijen G, Dixon LE, Troein C, Corellou F, Bouget FY, et al. Circadian rhythms persist without transcription in a eukaryote. Nature 2011;469:554-8.

12. Bass J, Takahashi JS. Circadian rhythms: Redox redux. Nature 2011;469:476-8.

13. Sun Y, Hegamyer G, Colburn NH. Molecular cloning of five messenger RNAs differentially expressed in preneoplastic or neoplastic JB6 mouse epidermal cells: one is homologous to human tissue inhibitor of metalloproteinases-3. Cancer Res 1994;54:113944.

14. Jeong W, Park SJ, Chang TS, Lee DY, Rhee SG. Molecular mechanism of the reduction of cysteine sulfinic acid of peroxiredoxin to cysteine by mammalian sulfiredoxin. J Biol Chem 2006;281:14400-7.

15. Giustarini D, Rossi R, Milzani A, Colombo R, Dalle-Donne I. S-glutathionylation: from redox regulation of protein functions to human diseases. J Cell Mol Med 2004;8:201-12.

16. Findlay VJ, Tapiero H, Townsend DM. Sulfiredoxin: a potential therapeutic agent? Biomed Pharmacother 2005;59:374-9.

17. Kayama Y, Raaz U, Jagger A, Adam M, Schellinger IN, Sakamoto M, et al. Diabetic Cardiovascular Disease Induced by Oxidative Stress. Int J Mol Sci 2015;16:25234-63.

18. Shi S, Guo Y, Lou Y, Li Q, Cai X, Zhong X, et al. Sulfiredoxin involved in the protection of peroxiredoxins against hyperoxidation in the early hyperglycaemia. Exp Cell Res 2017;352:273-80.

19. Shen Y, Chen S, Zhao Y. Sulfiredoxin-1 alleviates high glucoseinduced podocyte injury though promoting Nrf2/ARE signaling via inactivation of GSK-3beta. Biochem Biophys Res Commun 2019;516:1137-44.

20. Maritim AC, Sanders RA, Watkins JB. Diabetes, oxidative stress, and antioxidants: a review. J Biochem Mol Toxicol 2003;17:24-38.

21. Erejuwa O. Oxidative stress in diabetes mellitus: Is there a role for hypoglycemic drugs and/or antioxidants? In: Lushchak VI, Gospodaryov DV, editors. Oxidative Stress and Diseases. IntechOpen: Rijeka, Croatia; 2012.

22. Konrad T, Vicini P, Kusterer K, Hoflich A, Assadkhani A, Bohles $\mathrm{HJ}$, et al. Alpha-Lipoic acid treatment decreases serum lactate and pyruvate concentrations and improves glucose effectiveness in lean and obese patients with type 2 diabetes. Diabetes Care 1999;22:2807.

23. Arriaga D. Role of reactive oxygen species in gestational diabetes and the impact on the developing fetus. FASEB J 2018;32(Suppl 1):719.17.

24. Buchanan TA, Xiang AH, Page KA. Gestational diabetes mellitus: risks and management during and after pregnancy. Nat Rev Endocrinol 2012;8:639-49.

25. Mirghani Dirar A, Doupis J. Gestational diabetes from A to Z. World J Diabetes 2017;8:489-511.

26. Nguyen T, Sherratt PJ, Pickett CB. Regulatory mechanisms controlling gene expression mediated by the antioxidant response element. Ann Rev Pharmacol Toxicol 2003;43:233-60.

27. Kim KS, Choi SY, Kwon HY, Won MH, Kang TC, Kang JH. Aggregation of alpha-synuclein induced by the $\mathrm{Cu}, \mathrm{Zn}$-superoxide dismutase and hydrogen peroxide system. Free Radic Biol Med 2002;32:544-50.

28. Wood ZA, Poole LB, Karplus PA. Peroxiredoxin evolution and the regulation of hydrogen peroxide signaling. Science 2003;300:6503.

29. Ma C, Liu Y, He S, Zeng J, Li P, Ma C, et al. Association between glucose fluctuation during 2-hour oral glucose tolerance test, inflammation and oxidative stress markers, and beta-cell function in a Chinese population with normal glucose tolerance. Ann Transl Med 2021;9:327.

30. Aouache R, Biquard L, Vaiman D, Miralles F. Oxidative Stress in Preeclampsia and Placental Diseases. Int J Mol Sci 2018;19:1496. 